\title{
Mycobacterium leprae virulence-associated peptides are indicators of exposure to M. leprae in Brazil, Ethiopia and Nepal
}

\author{
Kidist Bobosha',2, Sheila Tuyet Tang ${ }^{3}$, Jolien J van der Ploeg-van Schip', Yonas Bekele², \\ Marcia VSB Martins ${ }^{4}$, Ole Lund ${ }^{3}$, Kees LMC Franken', Saraswoti Khadge ${ }^{5}$, \\ Maria Araci de Andrade Pontes ${ }^{6}$, Heitor de Sá Gonçalves ${ }^{6}$, Jemal Hussien², Pratibha Thapa ${ }^{5}$, \\ Chhatra B Kunwar ${ }^{5}$, Deanna A Hagge ${ }^{5}$, Abraham Aseffa ${ }^{2}$, Maria Cristina Vidal Pessolani ${ }^{4}$, \\ Geraldo MB Pereira ${ }^{7}$, Tom HM Ottenhoff' ${ }^{1}$, Annemieke Geluk ${ }^{1 /+}$
}

\author{
'Department of Infectious Diseases, University Medical Center, Leiden, The Netherlands ${ }^{2}$ Armauer Hansen Research Institute, \\ Addis Ababa, Ethiopia ${ }^{3}$ Center for Biological Sequence Analysis, Technical University Denmark, Lyngby, Denmark \\ ${ }^{4}$ Laboratório de Microbiologia Celular, Instituto Oswaldo Cruz-Fiocruz, Rio de Janeiro, RJ, Brasil \\ ${ }^{5}$ Mycobacterial Research Laboratory, Anandaban Hospital, Kathmandu, Nepal ${ }^{6}$ Centro Dermatológico Dona Libânia, Fortaleza, CE, Brasil \\ ${ }^{7}$ Faculdade de Ciências Médicas, Universidade do Estado do Rio de Janeiro, Rio de Janeiro, RJ, Brasil
}

Silent transmission of Mycobacterium leprae, as evidenced by stable leprosy incidence rates in various countries, remains a health challenge despite the implementation of multidrug therapy worldwide. Therefore, the development of tools for the early diagnosis of $\mathrm{M}$. leprae infection should be emphasised in leprosy research. As part of the continuing effort to identify antigens that have diagnostic potential, unique $\mathrm{M}$. leprae peptides derived from predicted virulenceassociated proteins (group IV.A) were identified using advanced genome pattern programs and bioinformatics. Based on human leukocyte antigen (HLA)-binding motifs, we selected 21 peptides that were predicted to be promiscuous HLA-class I T-cell epitopes and eight peptides that were predicted to be HLA-class II restricted T-cell epitopes for field-testing in Brazil, Ethiopia and Nepal. High levels of interferon (IFN)- $\gamma$ were induced when peripheral blood mononuclear cells (PBMCS) from tuberculoid/borderline tuberculoid leprosy patients located in Brazil and Ethiopia were stimulated with the ML2055 p35 peptide. PBMCs that were isolated from healthy endemic controls living in areas with high leprosy prevalence $\left(E C_{\text {high }}\right)$ in Ethiopia also responded to the ML2055 335 peptide. The Brazilian $E C_{\text {high }}$ group recognised the ML1358 p20 and ML1358 p24 peptides. None of the peptides were recognised by PBMCs from healthy controls living in non-endemic region. In Nepal, mixtures of these peptides induced the production of IFN- $\gamma$ by the PBMCs of leprosy patients and $E C_{\text {high }}$. Therefore, the $\mathrm{M}$. leprae virulence-associated peptides identified in this study may be useful for identifying exposure to $\mathrm{M}$. leprae in population with differing HLA polymorphisms.

Key words: M. leprae - leprosy - biomarkers - bioinformatics - virulence - peptides

Despite the decrease in the prevalence of leprosy since the introduction of multidrug therapy (MDT) over 30 years ago, new cases are still reported annually at a consistent rate in a number of countries. This observation indicates a continued and significant transmission of leprosy at the population level that presents a challenge for disease control efforts (WHO 2011). The incubation period for Mycobacterium leprae and the time that elapses before observable symptoms in an infected individual range between four-10 years, with a maximum of 30 years (Britton \& Lockwood 2004). It is hypothesised that most patients are subclinically infected for a considerable period of time before the infection becomes apparent. Therefore, subclinical infection may represent a major source of $M$. leprae transmission.

Financial support: NLR/ILEP (7.01.02.48), Turing Foundation/IDEAL (702.02.68), Order of Malta Grants for Leprosy Research, QM Gastmann-Wichers Foundation

+ Corresponding author: a.geluk@lumc.nl

Received 8 March 2012

Accepted 3 July 2012
Early detection of leprosy infection and timely treatment with MDT will help reduce transmission and infection and could prevent damage to nerves, disabilities and deformities. However, there are no diagnostic tests that are currently available that can detect asymptomatic $M$. leprae infection. The development of specific immunodiagnostic tools for leprosy infection requires adequate information about the pathogen-associated antigens. The inability to culture $M$. leprae on artificial media (Truman \& Krahenbuhl 2001) has greatly hampered leprosy research for many decades and has prevented the development of specific diagnostic tools for leprosy infection. The recent availability of improved bioinformatics tools and the genome sequence of $M$. leprae have resulted in new possibilities for leprosy research. These advances have enabled the prediction of relevant $M$. leprae proteins and potential human leukocyte antigen (HLA) class I and class II epitopes that can activate T-cells (Geluk et al. 2011). The use of unique $M$. leprae antigens that were identified using post-genomic approaches has resulted in the detection of $M$. leprae protein or peptide-specific $\mathrm{T}$-cell responses. These responses may help identify M. leprae-exposed or infected individuals (Geluk et al. 2005, 2009, Spencer et al. 2005, Araoz et al. 2006, Bobosha et al. 2011, 2012). 
Antigenic proteins typically contain multiple peptide epitopes. Therefore, antigenic proteins may be preferred diagnostic tools for use in populations with diverse genetic backgrounds. However, compared with the use of antigenic proteins as diagnostic tools, peptides have reduced or absent T-cell cross-reactivity (Geluk et al. 2008, 2009). Therefore, analysing unique M. leprae peptides or pools of peptides in different regions that are endemic for leprosy infection could be useful for identifying peptides that have diagnostic potential. The immunogenic and diagnostic significance of the Mycobacterium tuberculosis (Mtb) proteins ESAT-6 and CFP-10 and peptides derived from the RD-1 region (involved in enhancing virulence) (Arend et al. 2000) have led us to search for similar unique $M$. leprae virulence-associated peptides. In the current study, the complete proteome of $M$. leprae was dissected in silico into 20-mer amino acid peptides. Next, unique $M$. leprae peptides derived from group IV.A (virulence) (sanger.ac.uk/Projects/M leprae/Ml_gene_list_hierarchical.shtml) that were predicted to bind promiscuously to HLA class I or class II alleles were selected and synthesised. In vitro analysis of these synthetic peptides was performed using peripheral blood mononuclear cells (PBMCs) or whole blood isolated from lepromatous leprosy/borderline tuberculoid (TT/BT) and borderline lepromatous/lepromatous leprosy (BL/LL) patients and healthy endemic controls (ECs) who were located in Brazil, Ethiopia and Nepal in areas with high $\left(\mathrm{EC}_{\text {high }}\right)$ or low $\left(\mathrm{EC}_{\text {low }}\right)$ leprosy prevalence.

\section{SUBJECTS, MATERIALS AND METHODS}

Peptide identification strategy - The peptide identification procedure is depicted in Fig. 1. All of the 20mer peptides in the M. leprae genome (Cole et al. 2001) were identified. A length of 20 amino acids was chosen because this size allows for both HLA class I and class II T-cell epitopes. The 20-mer peptides that had eight or more amino acid overlap in a continuous stretch with sequences from other mycobacteria, compared with complete or nearly complete genomes sequences available in the GenBank sequence database (ncbi.nlm.nih.gov/ GenBank), were excluded from this study. The selection procedure is described in more detail below.

Bacterial genome sequences - All of the genome sequences that were used in this study were obtained from GenBank. The following six complete mycobacterial genomes were used: M. leprae (GenBank Protein accession NC_002677), Mtb strains H37Rv (AL123456 and NC_000962) and CDC1551 (NC_002755), Mycobacterium bovis (NC_002945) and Mycobacterium avium paratuberculosis (NC_002944). Other nearly complete mycobacterial genome sequences (unpublished at the time of peptide selection), such as those from $M$. avium, Mycobacterium smegmatis, Mtb strain 210 (tigr.org), Mycobacterium marinum, Mycobacterium microti (sanger. org), Mycobacterium paratuberculosis and Mycobacterium ulcerans (pasteur.fr/), were also included, using Basic Local Alignment Search Tool (BLAST) to allow a broader understanding of the conservation of the 20 -mer sequences across different mycobacterial species.
Bioinformatics tools - The complete $M$. leprae genome was divided into 20-mer peptide sequences with an overlap of 19 amino acids using the Genome Patterns program (M. leprae list). To check the homology of the $M$. leprae sequences with other, closely related mycobacterial genomes, the Genome Patterns program was also used to generate a list of 20-mer peptide sequences with an overlap of 19 amino acids for the Mtb strains H37Rv and CDC1551, M. bovis and M. paratuberculosis (the MTB list). The M. leprae list was compared with the $M T B$ list and all of the 20-mer peptide sequences that had a continuous stretch of eight or more identical amino acids between the lists were excluded from further analysis. This filtering step resulted in 141,300 20-mer peptide sequences that are unique to the $M$. leprae genome. Any of the 20-mer peptide sequences that were encoded by the $1,116 M$. leprae pseudogenes were then excluded. This process reduced the M. leprae list to 138,938 20 -mer peptide sequences derived from 1,546 different M. leprae candidate proteins. To reduce the number of candidate peptides for BLAST, we selected peptides that were derived from genes in the functional classification group IV.A (virulence) (included the following 13 genes: ML0360, ML0361, ML0362, ML0885, ML1214, ML1358, ML1811, ML1812, ML2055, ML2208, ML2466, ML2589, ML2711) (sanger.ac.uk/Projects/M_leprae/Ml_gene_ list_hierarchical.shtml, currently designated as "genes involved in virulence, detoxification and adaptation" or "genes involved in cell wall and cell processes" on mycobrowser.epfl.ch/leprosy.html). This step resulted in 886 candidate 20-mer peptide sequences. Next, we used a Perl script entitled "genediff.pl" that compared the genome

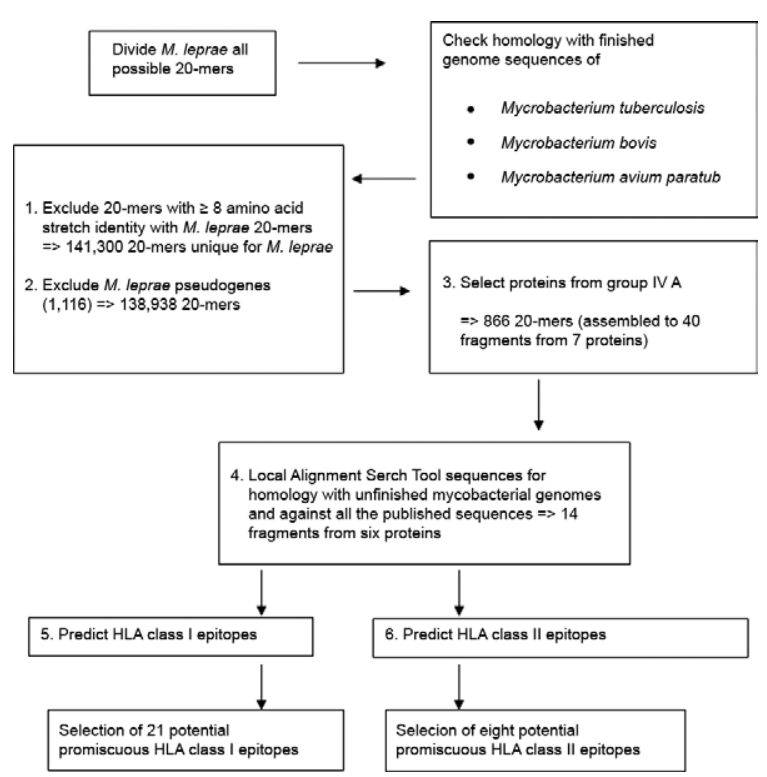

Fig. 1: Mycobacterium leprae peptide selection procedure. Identification and selection of predicted M. leprae promiscuous human leukocyte antigen (HLA) class I epitopes $(\mathrm{n}=21)$ and predicted $M$. leprae promiscuous HLA class II epitopes $(\mathrm{n}=8)$ derived from $M$. leprae proteins from functional classification group IV.A (virulence) (sanger.ac.uk/Projects/M_leprae/Ml_gene_list_hierarchical.shtml). 
sequences by BLAST analysis (CBS, script used internally) and excluded proteins that were homologous to the human genome and to three Mtb homologs. The M. leprae-derived 20-mer peptide sequences that overlapped were then assembled (if the peptides were arranged in sequential order within the genome), resulting in a total of 40 protein fragments. BLAST analysis was then used to exclude protein fragments that were also found in the incomplete genome sequences of M. smegmatis, Mtb strain 210 and M. microti OV254 (sanger.org and tigr. org). The assembled M. leprae fragments were then analysed by BLAST analysis against all sequences that were available in GenBank (ncbi.nlm.nih.gov/blast/). All of the sequences that had shared more than eight amino acids with the M. leprae peptides were again excluded. Of the 40 fragments, 14 peptide fragments from six proteins were determined to be unique to $M$. leprae.

Prediction of CD4 and CD8-restricted T-cell epitopes - NetCTL version 1.2 (cbs.dtu.dk/services/ NetCTL) was used to predict 9-mer peptide epitopes from the 14 unique $M$. leprae fragments for 12 HLA supertypes (HLA-A1, A2, A3, A24, A26 and HLA-B7, B8, B27, B39, B44, B58, B62) (Larsen et al. 2005). All of the peptides that had a combined score in excess of 1.25 were selected as potential major histocompatibility complex class I ligands. An adapted version of the TEPITOPE program (Singh \& Raghava 2003) was used to predict CD4-restricted T-cell epitopes from the 14 unique $M$. leprae fragments that were identified from six M. leprae proteins. The six protein sequences were submitted to the SubCell 1.0 server (cbs.dtu.dk/services/) to predict the subcellular localisation of these proteins in Gram-negative and Gram-positive bacteria. From the resulting sequences, peptides were selected that contained predicted binding sequences for most of the HLA alleles. For this selection, priority was given to peptides that were predicted to bind promiscuously to multiple HLA alleles (Table I). This process resulted in 21 potential CD8-restricted T-cell epitopes and eight potential CD4-restricted T-cell epitopes (Tables I, II). In the event that a positive CD4 T-cell response is induced after stimulation with the 9-mer peptides (potentially a suboptimal length), only the strongest inducers will be identified using this approach.

Synthetic peptides - The virulence-associated $M$. leprae-derived peptides that were identified were purchased from Peptide 2.0 Inc (Chantilly, VA, USA). Homogeneity and purity were confirmed by analytical high-performance liquid chromatography and by mass spectrometry. The purity of all of the peptides was $\geq 80 \%$. All of the impurities that were identified consisted of shorter derivatives of the peptides that were caused by coupling efficiency that was $<100 \%$ for each round of peptide synthesis. All of the peptides

\section{TABLE I}

Selected Mycobacterium leprae virulence-associated peptides

[human leukocyte antigen (HLA) class I, $\mathrm{n}=21$ ]

\begin{tabular}{|c|c|c|c|c|c|c|c|}
\hline & $\begin{array}{l}\text { Peptide } \\
(9 \text {-mer) }\end{array}$ & $\begin{array}{l}\text { Starting- } \\
\text { position }\end{array}$ & $\begin{array}{c}\text { ML } \\
\text { accession }\end{array}$ & Accession & HLA & HLA & HLA \\
\hline p15 & RAAVVQAAL & 262 & ML0885 & NP_301670.1_245_270 & B7 & B8 & B58 \\
\hline p16 & SMDAAVAAL & 193 & ML1812 & NP_302233.1_181_201 & A 2 & B39 & - \\
\hline p17 & GIAGSASYY & 202 & ML2055 & NP_302372.1_189_211 & A1 & B62 & - \\
\hline p18 & HRKGLWAIL & 10 & ML2055 & NP_302372.1_1_78 & B27 & B39 & - \\
\hline p19 & QMLEASSSV & 210 & ML1811 & NP_302232.1_209_232 & A2 & - & - \\
\hline $\mathrm{p} 20$ & ALDTFGIPV & 73 & ML1358 & NP_301968.1_64_92 & A2 & - & - \\
\hline $\mathrm{p} 21$ & NGIAGSASY & 201 & ML2055 & NP_302372.1_189_211 & A26 & - & - \\
\hline $\mathrm{p} 22$ & KVTVSSVRK & 220 & ML1811 & NP_302232.1_209_232 & A3 & - & - \\
\hline $\mathrm{p} 23$ & TEAVHSAQL & 58 & ML0885 & NP_301670.1_54_76 & B44 & - & - \\
\hline $\mathrm{p} 24$ & KLMGALDTF & 69 & ML1358 & NP_301968.1_64_92 & B58 & - & - \\
\hline p25 & VASASAFTM & 23 & ML2055 & NP_302372.1_1_78 & B58 & - & - \\
\hline p26 & AVVASASAF & 21 & ML2055 & NP_302372.1_1_78 & B62 & - & - \\
\hline p27 & APLPPSTAT & 42 & ML2055 & NP_302372.1_1_78 & B7 & - & - \\
\hline $\mathrm{p} 28$ & GPVPAVATL & 220 & ML0885 & NP_301670.1_220_250 & B7 & - & - \\
\hline p29 & IPVAGRCCL & 79 & ML1358 & NP_301968.1_64_92 & B7 & - & - \\
\hline p30 & RPRRGSVSR & 3 & ML1812 & NP_302233.1_1_20 & B7 & - & - \\
\hline p31 & LPSADIVPM & 172 & ML1358 & NP_301968.1_158_181 & B7 & - & - \\
\hline p32 & SASAFTMPL & 25 & ML2055 & NP_302372.1_1_78 & B7 & - & - \\
\hline p33 & APIPASVSA & 274 & ML2055 & NP_302372.1_257_287 & B7 & - & - \\
\hline p34 & RPVPVSTAR & 204 & ML1214 & NP_301879.1_173_212 & B7 & - & - \\
\hline p35 & IPASVSAPA & 276 & ML2055 & NP_302372.1_257_287 & B7 & - & - \\
\hline
\end{tabular}


were divided into aliquots to allow the field testing of identical batches of peptides in Brazil, Ethiopia, Nepal and The Netherlands.

M. leprae recombinant proteins - The M. leprae genes that encoded the proteins from which the virulence-associated peptides were derived were polymerase chain reaction-amplified from genomic $M$. leprae DNA. The genes were then cloned using the Gateway technology platform (Invitrogen, Carlsbad, CA, USA) using the pDEST17 expression vector, which contains an N-terminal histidine tag (Invitrogen) (Franken et al. 2000). Sequencing was performed on selected clones to confirm the identity of all of the cloned DNA fragments. The recombinant proteins were overexpressed in BL21 Escherichia coli (DE3) and purified to remove endotoxins (Franken et al. 2000). To confirm size and purity, each purified recombinant protein was analysed by $12 \%$ sodium dodecyl sulfate polyacrylamide gel electrophoresis followed by Coomassie Brilliant Blue staining and Western blotting using an anti-His antibody (Invitrogen). Endotoxin levels were below 50 endotoxin units per $\mathrm{mg}$ of recombinant protein as determined using a limulus amebocyte lysate QCL-1000 assay (Lonza Inc, Basel, Switzerland). Recombinant proteins were tested in interferon (IFN)- $\gamma$ release assays to exclude the possibility of non-specific T-cell stimulation and cellular toxicity. For this assay, PBMCs from purified protein derivative (PPD)-negative, healthy Dutch donors were recruited at the Blood Bank in Sanquin, Leiden, The Netherlands. None of the healthy control individuals had any known prior contact with leprosy or tuberculosis (TB) patients.

M. leprae whole cell sonicate (WCS) - Irradiated, armadillo-derived $M$. leprae whole cells were probesonicated using a Sanyo sonicator to $>95 \%$ breakage. These cells were obtained through the National Institutes of Health/National Institute of Allergy and Infectious Diseases Leprosy Research Support Contract N01 AI-25469 from the Colorado State University (available through the Biodefense and Emerging Infections Research Resources Repository available from beiresources.org/TBVTRMResearch Materials/tabid/1431/Default.aspx).
Study participants - Human immunodeficiency virus (HIV)-negative individuals were recruited between August 2008-February 2011 from each region of study. In Brazil, 10 TT/BT leprosy patients, 10 healthy controls $\left(\mathrm{EC}_{\text {low }}\right)$ living in an area of Fortaleza (Mereiles) with low leprosy prevalence $(<0.2 / 10,000)$ and 10 healthy controls $\left(\mathrm{EC}_{\text {high }}\right)$ living in other area of Fortaleza (Bom Jardin) with relatively high leprosy prevalence $(>4 / 10,000$; $)$ were recruited. In Ethiopia, 23 leprosy patients (10 TT/ $\mathrm{BT}$ and $13 \mathrm{BB} / \mathrm{BL}$ ), 12 house hold contacts (HHCs) of $\mathrm{BL} / \mathrm{LL}$ patients and 52 healthy controls were recruited. Of the healthy controls, $25 \mathrm{EC}_{\text {high }}$ were located in a subcity of Addis Ababa (Kolfe Keranio) that had a prevalence rate of 1.5 per 10,000 (72 in 465,811$)$ and $27 \mathrm{EC}_{\text {low }}$ were located in areas that had a prevalence rate of 0.36 per 10,000 (10 in 273,310). The endemicity of leprosy for both of the Ethiopian EC groups was determined by the number of new cases of leprosy and the prevalence of leprosy in nearby health centres. In Nepal, seven TT/ $\mathrm{BT}$ and five $\mathrm{BL} / \mathrm{LL}$ patients and $20 \mathrm{EC}_{\text {high }}$ were enrolled in this study. The national prevalence of leprosy in $\mathrm{Ne}$ pal was 1.1 per 10,000 in 2008/2009 (Annual Report 2008/2009, Leprosy Control Division, Nepal).

In all of the regions, leprosy was diagnosed based on clinical, bacteriological and histological observations. The leprosy patients were classified as TT/BT or BB/ BL/LL by a skin biopsy that was evaluated according to the Ridley and Jopling (1996) classification by qualified microbiologists and pathologists. All of the patients who were recruited had been newly diagnosed, were untreated and did not develop leprosy reactions within three months after MDT initiation. ECs were assessed for the absence of clinical signs and symptoms of TB and leprosy. Staff members working in the leprosy centres or TB clinics were excluded from this study.

$24 \mathrm{~h}$ whole blood assays (WBA) - Within $3 \mathrm{~h}$ after collection, venous, heparinised blood $(450 \mu \mathrm{L} /$ well $)$ was incubated with $50 \mu \mathrm{L}$ of antigen solution $(100 \mu \mathrm{g} / \mathrm{mL})$ in 48 -well plates at $37^{\circ} \mathrm{C}$ under $5 \% \mathrm{CO}_{2}$ and $90 \%$ relative humidity. After $24 \mathrm{~h}$ incubation, $150 \mu \mathrm{L}$ of supernatant was removed from each well and aliquots were frozen at $-20^{\circ} \mathrm{C}$ until further analysis.

\section{TABLE II}

Selected Mycobacterium leprae virulence-associated peptides

[human leukocyte antigen (HLA) class II, $\mathrm{n}=8$ ]

\begin{tabular}{|c|c|c|c|c|c|c|c|}
\hline & $\begin{array}{l}\text { Peptide } \\
\text { (9-mer) }\end{array}$ & $\begin{array}{l}\text { Starting- } \\
\text { position }\end{array}$ & ML accession & Accession & HLA & HLA & HLA \\
\hline p36 & VVRDLRLRA & 197 & ML1358 & NP_301968.1_192_213 & 1_0301 & 1_1101 & $1 \_1501$ \\
\hline p37 & WAILAIAVV & 15 & ML2055 & NP_302372.1_1_78 & 1_0101 & 1_0801 & $1 \_1101$ \\
\hline $\mathrm{p} 38$ & ILAIAVVAS & 17 & ML2055 & NP_302372.1_1_78 & 1_0301 & 1_0401 & $1 \_1101$ \\
\hline p39 & VRPVPVSTA & 203 & ML1214 & NP_301879.1_173_212 & 1_0301 & 1_1101 & - \\
\hline $\mathrm{p} 40$ & LRADSVLAV & 203 & ML1358 & NP_301968.1_192_213 & 1_0301 & 1_0401 & - \\
\hline p41 & LQQVPTLPA & 199 & ML1214 & NP_301879.1_173_212 & 1_1101 & - & - \\
\hline p42 & LAIAVVASA & 18 & ML2055 & NP_302372.1_1_78 & 1_1101 & - & - \\
\hline $\mathrm{p} 43$ & ISLATVLSA & 158 & ML1358 & NP_301968.1_158_181 & $1 \_1101$ & - & - \\
\hline
\end{tabular}


Lymphocyte stimulation tests (LST) - PBMCs were isolated by Ficoll density centrifugation of venous, heparinised blood and the PBMCs were plated in triplicate cultures $\left(2 \times 10^{5}\right.$ cells/well) in $200 \mu \mathrm{L} /$ well of serum-free adoptive immunotherapy medium (AIM-V) (Invitrogen, Carlsbad, CA) in 96-well round bottom plates (Costar Corporation, Cambridge, USA). Synthetic peptides, recombinant protein, M. leprae WCS or PPD (Mtb, Statens Serum Institut, Copenhagen, Denmark) were added at final concentrations of $10 \mu \mathrm{g} / \mathrm{mL}$. A positive control of $1 \mu \mathrm{g} / \mathrm{mL}$ phytohaemagglutinin (PHA) (Remel, Oxoid, Haarlem, The Netherlands) was also used. After six days of culture at $37^{\circ} \mathrm{C}$ under $5 \% \mathrm{CO}_{2}$ and $90 \%$ relative humidity, $75 \mu \mathrm{L}$ of supernatant was removed from each well. Triplicate samples were pooled and frozen in aliquots at $-20^{\circ} \mathrm{C}$ until further analysis.

$I F N-\gamma$ ELISA - IFN- $\gamma$ concentrations were determined by ELISA (U-CyTech, Utrecht, The Netherlands) (Geluk et al. 2005). The cut-off value to designate a positive response was set prior to experimentation at $100 \mathrm{pg} /$ $\mathrm{mL}$. The sensitivity level of the assay was $40 \mathrm{pg} / \mathrm{mL}$. The values for unstimulated cell cultures were typically $<20 \mathrm{pg} / \mathrm{mL}$. Lyophilised supernatant from PHA-stimulated cultures of PBMCs from an anonymous buffycoat (Sanquin, Leiden, The Netherlands) was provided as a positive control supernatant.

Multi-cytokine and multi-chemokine assay - The concentrations of 19 chemokines or cytokines [interleukin (IL)-1B, IL-2, IL-4, IL-5, IL-6, IL-7, IL-8, IL-10, IL12p70, IL-13, IL-17A, IFN- $\gamma$, induced protein-10 (IP-10) (CXCL10), granulocyte colony-stimulating factor (GCSF), granulocyte macrophage colony-stimulating factor (GM-CSF), monocyte chemoattractant protein-1 (CCL2), monokine induced by IFN- $\gamma$ (CXCL9), macrophage inflammatory protein-1 $\beta$ (CCL4) and tumour necrosis factor] in the supernatants from $24 \mathrm{~h} \mathrm{WBA}$ were measured using the Bio-Plex suspension array system powered by the Luminex xMap multiplex technology (Bio-Rad Laboratories, Veenendaal, The Netherlands) and analysed using the Bio-Plex Manager ${ }^{\mathrm{TM}}$ software 6.0 (Bio-Rad Laboratories, Veenendaal, The Netherlands). After pre-wetting the filter with the assay solution, magnetic beads were washed twice with washing solution using 96-well multiscreen filter plates (Millipore), an Aurum ${ }^{\mathrm{TM}}$ vacuum manifold and a vacuum pump (Bio-Rad Laboratories, Veenendaal, The Netherlands). Supernatant samples $(50 \mu \mathrm{L})$ were added to the plates and the plates were incubated for $45 \mathrm{~min}$ at room temperature (RT) in the dark on a plate shaker at $300 \mathrm{rpm}$. After three washes, $12.5 \mu \mathrm{L}$ of the detection antibody cocktail was added to each well and the plates were then incubated at RT in the dark for $30 \mathrm{~min}$ on a plate shaker. After three washes, $25 \mu \mathrm{L}$ of streptavidin-PE solution was added per well and the plates were incubated for $10 \mathrm{~min}$. After three washes, $80 \mu \mathrm{L}$ of assay buffer was added to each well and the plates were placed in the BioPlex System. A minimum of 50 analyte-specific beads were analysed from each well for fluorescence. A fitting curve was applied to each standard according to the manufacturer's manual. The sample concentrations were interpolated from these standard curves. Concentrations of analytes that were outside the upper or lower limits of quantification were designated as concentrations equal to the limit of quantification for the cytokine or chemokine.

Statistical analysis - Differences in cytokine concentration between the test groups were analysed by a twotailed Mann-Whitney $U$-test for non-parametric distributions using GraphPad Prism version 5.0 for Windows (GraphPad Software, San Diego California USA) (graphpad.com). p-values were corrected for multiple comparisons. The statistical significance level used was $\mathrm{p}<0.05$.

Ethics - This study was performed in accordance with the ethical standards of the Helsinki Declaration of 1975 and as revised in 1983. Ethical approval of the study was obtained through the following national or institutional ethics: the Brazilian National Council of Ethics in Research, the National Health Research Ethical Review Committee of Ethiopia and the Nepal Health Research Council. Informed consent was obtained from all individuals before venipuncture.

\section{RESULTS}

Post-genomic approach for improved, M. lepraespecific CMI test antigens - Because CD8-restricted epitopes are shorter than CD4-restricted epitopes, reliable bio-informatics methods to predict CD8-restricted epitopes were developed early (e.g., SYFPEITHI) (SYFPEITHI.de). More recently, methods to predict the longer CD4-restricted T-cell epitopes were designed using improved training sets and algorithms. Notably, the PROPRED program (imtech.res.in) has been demonstrated to accurately predict human T-cell epitopes and many of these epitopes have been confirmed experimentally (Sturniolo et al. 1999, Singh \& Raghava 2003). Using genomic sequences that are available and these improved bio-informatics tools, we identified unique $M$. leprae candidate antigens that were screened in silico to identify potential T-cell epitopes (Fig. 1, Materials and Methods section). Using this post-genomic approach, unique $M$. leprae epitope sequences derived from $M$. leprae functional group IV.A (virulence) proteins were identified. The synthetic peptides encoded by these unique sequences, which are designated in this study as M. leprae virulence-associated peptides (Table I), were used to evaluate cellular responses in leprosy patients and healthy controls from Brazil, Ethiopia and Nepal.

$T$-cell recognition of $M$. leprae peptides by non-ECs (NECS) - To exclude the possibility of nonspecific induction of T-cell responses by the selected M. leprae virulence-associated peptides, the peptides were first tested using a six day LST on PBMCs from Dutch healthy controls (NEC). These controls were also analysed in $24 \mathrm{~h}$ WBAs using undiluted venous blood. Most individuals were observed to have high responses to PPD (7/8) and M. leprae WCS (5/8). None of the NECs had a detectable IFN- $\gamma$ response against any of the individual peptides or the peptide pools (Fig. 2A). Similarly, no response was observed in the $24 \mathrm{~h}$ WBAs (Fig. 2B). These data demonstrate the absence of non-specific T-cell responses to the selected peptides. 
T-cell recognition of $M$. leprae peptides in PBMCs from the Brazilian test groups - The overall aim of our study was to identify new antigens that can specifically indicate M. leprae exposure and/or infection. Therefore, the $M$. leprae virulence-associated peptides (Table I) were first tested in a Brazilian population in a six day LST. For this study, TT/BT, healthy $\mathrm{EC}_{\text {high }}$ who lived in an urban area with relatively high leprosy prevalence $(p>4 / 10,000)$ and $\mathrm{EC}_{\text {low }}$ who lived in the same city in an area with low leprosy prevalence $(p<0.2 / 10,000)$ were enrolled. In the Brazilian $\mathrm{EC}_{\text {high }}$ group, $50 \%$ and $70 \%$ of the individuals specifically recognised ML1358 p20 and ML1358 p24 (Fig. 3A), respectively. None of the individuals from the $\mathrm{EC}_{\text {low }}$ group or the TT/BT group produced IFN- $\gamma$ in response to these two peptides (Fig. 3B). In contrast, stimulation with the ML2055 p35 induced considerable levels of IFN- $\gamma(>1000 \mathrm{pg} / \mathrm{mL})$ in $40 \%$ of the TT/BT patients. The ML1214 p41, ML1812 p30, ML2055 p31, ML2055 p37, ML2055 p39 and ML2055 p42 peptides induced IFN- $\gamma$ responses in $30-40 \%$ of this group, although the median IFN- $\gamma$ concentrations were lower (200 pg/mL) (Fig. 3C).
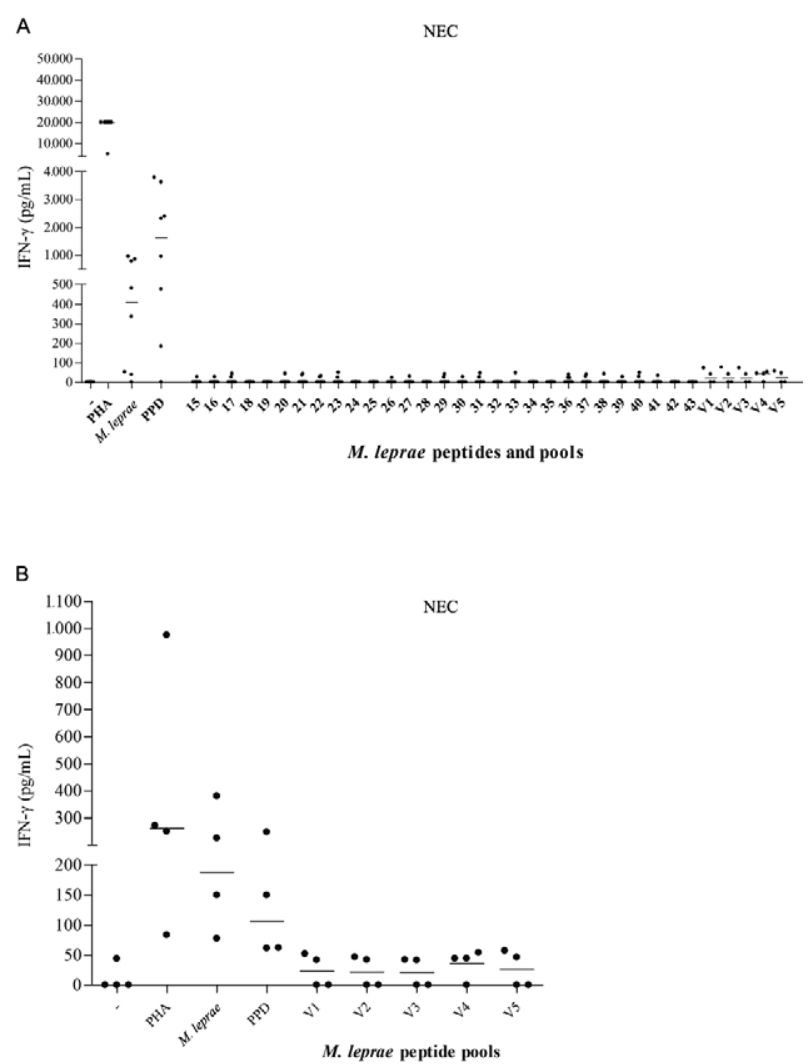

Fig. 2: interferon (IFN)- $\gamma$ responses to Mycobacterium leprae peptides in peripheral blood mononuclear cell (PBMC) from non-endemic controls (NEC). IFN- $\gamma$ production (corrected for background values) induced using $M$. leprae virulence-associated peptides or pools thereof (A) in six day PBMC cultures of Dutch healthy controls $(\mathrm{n}=8)$ or as pools in a $24 \mathrm{~h}$ whole blood assays (WBA) (B). Pool V1: 15-20; V2: 21-26; V3: 27-32; V4: 33-35, 37-39; V5: 36, 40-43 (numbers indicate peptide sequences depicted in Tables I, II). PHA: phytohaemagglutinin; PPD: purified protein derivative.
Recognition of M. leprae peptides by PBMCs from Ethiopian individuals - To analyse differences in genetic backgrounds, test groups from different leprosy endemic regions were included in this study. This diversity allowed the analysis of differences in the T-cell response as a result of HLA polymorphisms. Therefore, the $M$. leprae virulence-associated peptides were tested using PBMCs from 12 Ethiopian TT/BT leprosy patients (Fig. 3D) and seven EC (2 $\mathrm{EC}_{\text {high }}$ and $\left.5 \mathrm{EC}_{\text {low }}\right)$ (Fig. 3E). The IFN- $\gamma$ concentration in response to the $M$. leprae virulence-associated peptides in both groups was lower compared with the IFN- $\gamma$ concentration in the Brazil cohort. However, the ML2055 p35 peptide induced IFN- $\gamma$ production in $50 \%$ of the Ethiopian TT/BT patients (Fig. 3D), which was the case for the Brazilian TT/BT group. In addition, one of the $\mathrm{EC}_{\text {high }}$ individuals responded to eight out of the 28 peptides ( $>100 \mathrm{pg} / \mathrm{mL}$ ) (Fig. 3E). Therefore, the ML2055 p35 peptide is recognised most frequently in the TT/BT patients in Brazil and Ethiopia.

$I F N-\gamma$ responses in Ethiopian $E C_{\text {high }}$ and $E C_{\text {low }}$ in a $W B A$ - To identify peptides that have the ability to indicate exposure to $M$. leprae using a rapid field-assay, the ML2055 p35, ML2055 p42, ML2055 p37 and ML1358 p24 peptides were selected for comparative analysis in the Ethiopian $\mathrm{EC}_{\text {low }}(\mathrm{n}=17)$ and $\mathrm{EC}_{\text {high }}(\mathrm{n}=18)$ groups using a $24 \mathrm{~h}$ WBA. The ML2055 p35 and ML2055 p42 peptides, which were recognised by Brazilian TT/BT patients, also induced significant levels of IFN- $\gamma$ in the Ethiopian $\mathrm{EC}_{\text {high }}(\mathrm{p}=0.023$ and $\mathrm{p}=0.020$, respectively $)$ group compared with the $\mathrm{EC}_{\mathrm{low}}$ group (Fig. 4). The IFN- $\gamma$ levels in response to other $M$. leprae peptides were low and no significant differences were observed between the $\mathrm{EC}_{\text {high }}$ and $\mathrm{EC}_{\text {low }}$ groups.

$I P-10$ is a potential biomarker for diagnosis of $M$. leprae exposure - Although IFN- $\gamma$ is the hallmark effector molecule produced by Th1 cells and is a critical component of the pro-inflammatory immune response, host immunity and immunopathogenicity in response to $M$. leprae infection involve complex interactions between a variety of cells that express different effector and regulatory molecules. Thus, the analysis of multiple biomarkers may be more representative of the immune status of the host and may identify immune patterns that could predispose an individual to $M$. leprae infection. Therefore, aliquots of the $24 \mathrm{~h} \mathrm{WBA}$ samples from the Ethiopian $\mathrm{EC}_{\text {high }}$ and $\mathrm{EC}_{\text {low }}$ groups were used for the multiplex analysis of 19 additional cytokines and chemokines. The IFN- $\gamma$-IP-10 (or CXCL10) has been shown to be a useful biomarker for the diagnosis of Mtb infection (Singh \& Raghava 2003, Ruhwald et al. 2011). Interestingly, the ML2055 p35 protein induced significantly higher levels of IP-10 in the $\mathrm{EC}_{\text {high }}$ group, but not in the $\mathrm{EC}_{\text {low }}$ group ( $\mathrm{p}=0.005)$ (Fig. 4E). The ML2055 p42 peptide also induced increased levels of IP-10 production in the $\mathrm{EC}_{\text {high }}$ group compared with the $\mathrm{EC}_{\text {low }}$ group, although the difference between these two groups was not significant $(p=0.06)$ (Fig. 4F). None of the other analytes were observed to have significantly different levels between the $\mathrm{EC}_{\text {high }}-\mathrm{EC}_{\text {low }}$ groups (data not shown). Therefore, the elevated IP-10 levels that were induced by the M. leprae- 
specific antigens in the WBA from $\mathrm{EC}_{\mathrm{high}}$ indicate that this chemokine may have potential for use as a biomarker to differentiate levels of $M$. leprae exposure. Such a marker could be a new diagnostic tool that is similar to what has been reported for TB immunodiagnostic assays (Ruhwald et al. 2007, Aabye et al. 2010).

$I F N-\gamma$ production in response to $M$. leprae recombinant proteins - The M. leprae virulence-associated peptides that induced IFN- $\gamma$ responses by several individuals were derived from only a few proteins. In particular, p35, p37 and p42 were derived from ML2055, p20 and p24 were derived from ML1358 and p41 was derived from ML1214. To investigate the immunogenicity of the complete whole antigens, the recombinant proteins ML2055, ML1358 and ML1214 were tested in a $24 \mathrm{~h} \mathrm{WBA.} \mathrm{Ethi-}$ opian $\mathrm{BB} / \mathrm{BL}$ patients, HHCs and $\mathrm{ECs}\left(\mathrm{EC}_{\text {high }}: \mathrm{n}=7\right.$ and $\mathrm{EC}_{\text {low }}: \mathrm{n}=3$ ) (Fig. 5) were tested in this assay. The ML2055 protein induced an IFN- $\gamma$ response $(>100 \mathrm{pg} /$ $\mathrm{mL}$ ) in $60 \%$ (7 out of 13 ) of the $\mathrm{BB} / \mathrm{BL}$ patients and $42 \%$ (3 out of 7) of the $\mathrm{EC}_{\text {high }}$ individuals. However, only one

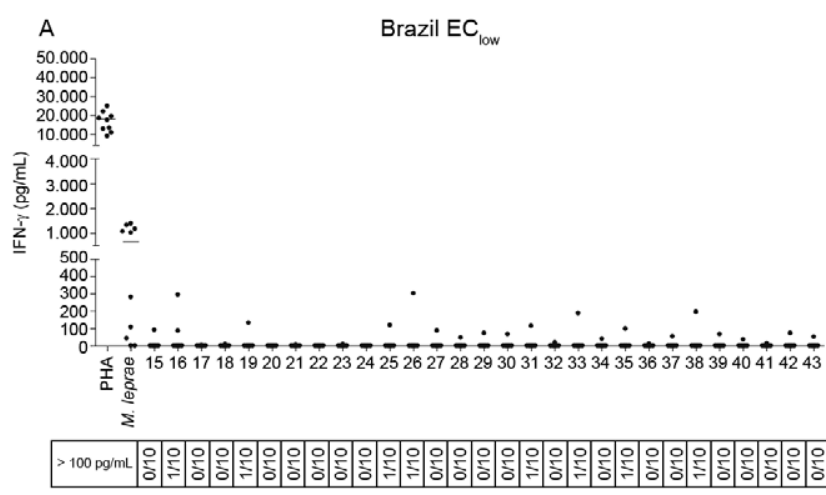

M. leprae peptides

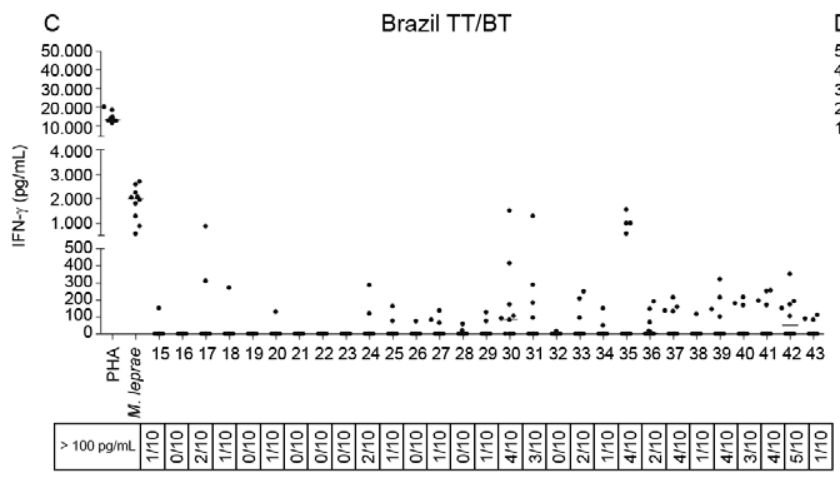

M. leprae peptides
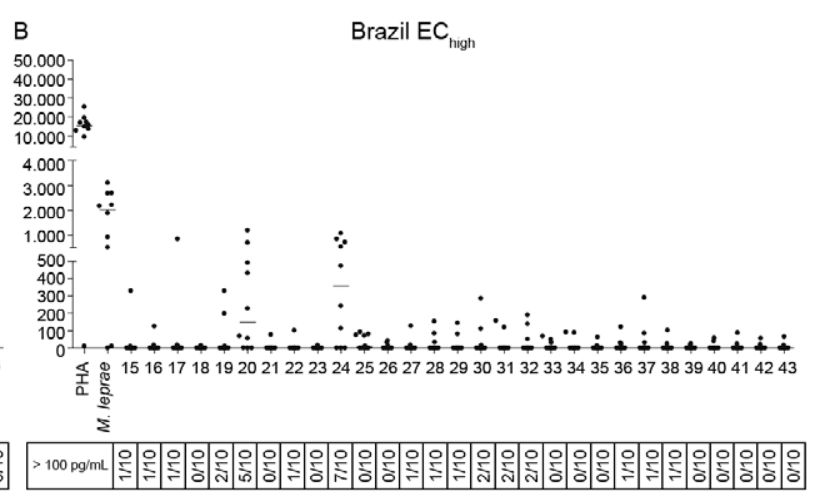

M. leprae peptides
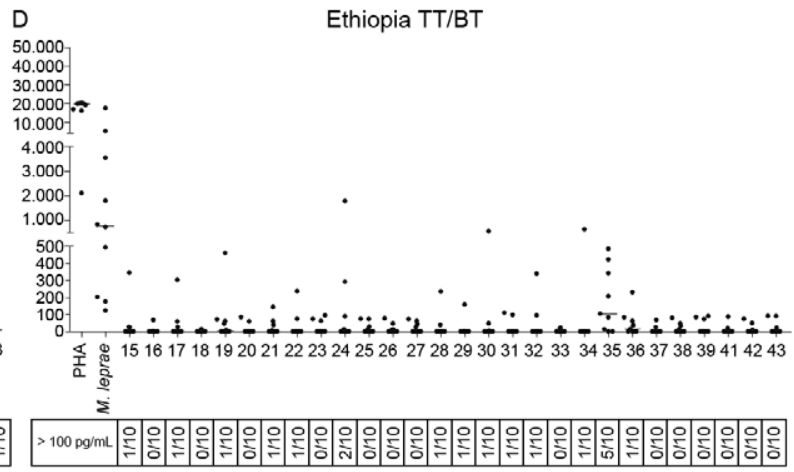

M. leprae peptides

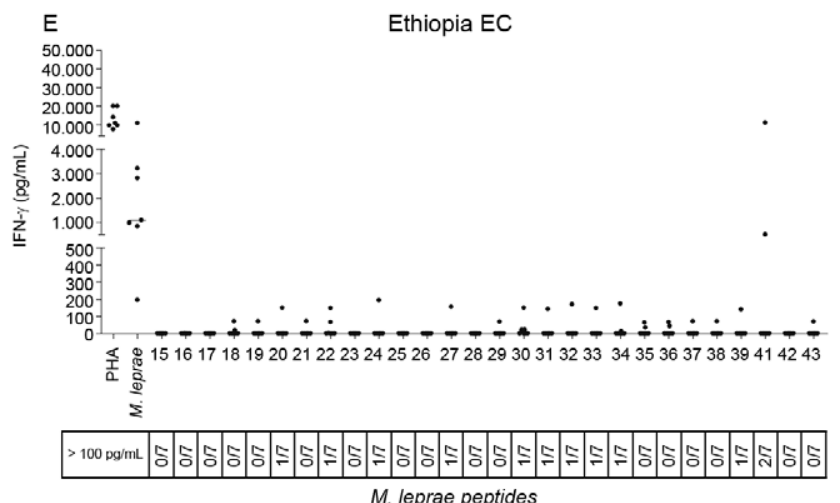

Fig. 3: interferon (IFN)- $\gamma$ responses to Mycobacterium leprae peptides in peripheral blood mononuclear cell (PBMC) from Brazilian and Ethiopian individuals. IFN- $\gamma$ production (corrected for background values) induced using $M$. leprae virulence-associated peptides in six day PBMC cultures of endemic controls (EC) from areas of Fortaleza, Brazil, with low prevalence $\left(\mathrm{EC}_{\mathrm{low}}\right)(\mathrm{A})(<0.2 / 10,000)(\mathrm{n}=10)$ and high prevalence $\left(\mathrm{EC}_{\text {high }}\right)(\mathrm{B})(>4 / 10,000)(\mathrm{n}=10)$ leprosy endemicity, Brazilian lepromatous leprosy/borderline tuberculoid $(\mathrm{TT} / \mathrm{BT}) \mathrm{patients}(\mathrm{C})(\mathrm{n}=10)$, Ethiopian TT/BT patients (D) $(n=10)$ and Ethiopian EC $(\mathrm{E})(\mathrm{n}=7)$. Median values per test group are indicated by horizontal lines. Background values were $<20 \mathrm{pg} / \mathrm{mL}$. 
of the HHCs produced a response against this protein. IFN- $\gamma$ responses against the ML1358 protein were very low in ECs and HHCs, but a significant percentage $(60 \%)$ of the $\mathrm{BB} / \mathrm{BL}$ patients responded to this protein. The ML1214 protein induced an IFN- $\gamma$ response in $69 \%$ of $\mathrm{BB} / \mathrm{BL}$ patients, $66 \%$ of HHCs and $60 \%$ of ECs.

$T$-cell responses to pools of $M$. leprae virulence-associated peptides in Nepal - Individuals from Nepal were also enrolled in this study to analyse the response by an Asian endemic population. The M. leprae virulence-associated peptides were tested in five peptide pools (V1: p15p20; V2: p21-p26; V3: p27-p32; V4: p33-p35, p37-p39; V5: p36, p40- p43) using PBMCs from Nepali leprosy patients and ECs. When peptide pools that contained p35, p37 and p42 from ML2055 (V3, V4 and V5) were screened in Ne$\mathrm{pal}$, the production of IFN- $\gamma$ was observed from PBMCs of ECs, but there was only a small response by PBMCs from leprosy patients prior to treatment (Fig. 6). Interestingly, after the completion of MDT, three out of the seven BT patients were observed to have increased concentrations of IFN- $\gamma$ production in response to stimulation with the peptide pools (Fig. 6C, F). These findings will need to be confirmed in larger patient cohorts, but these data indicated that the peptides used may have relevance in monitoring therapeutic intervention.
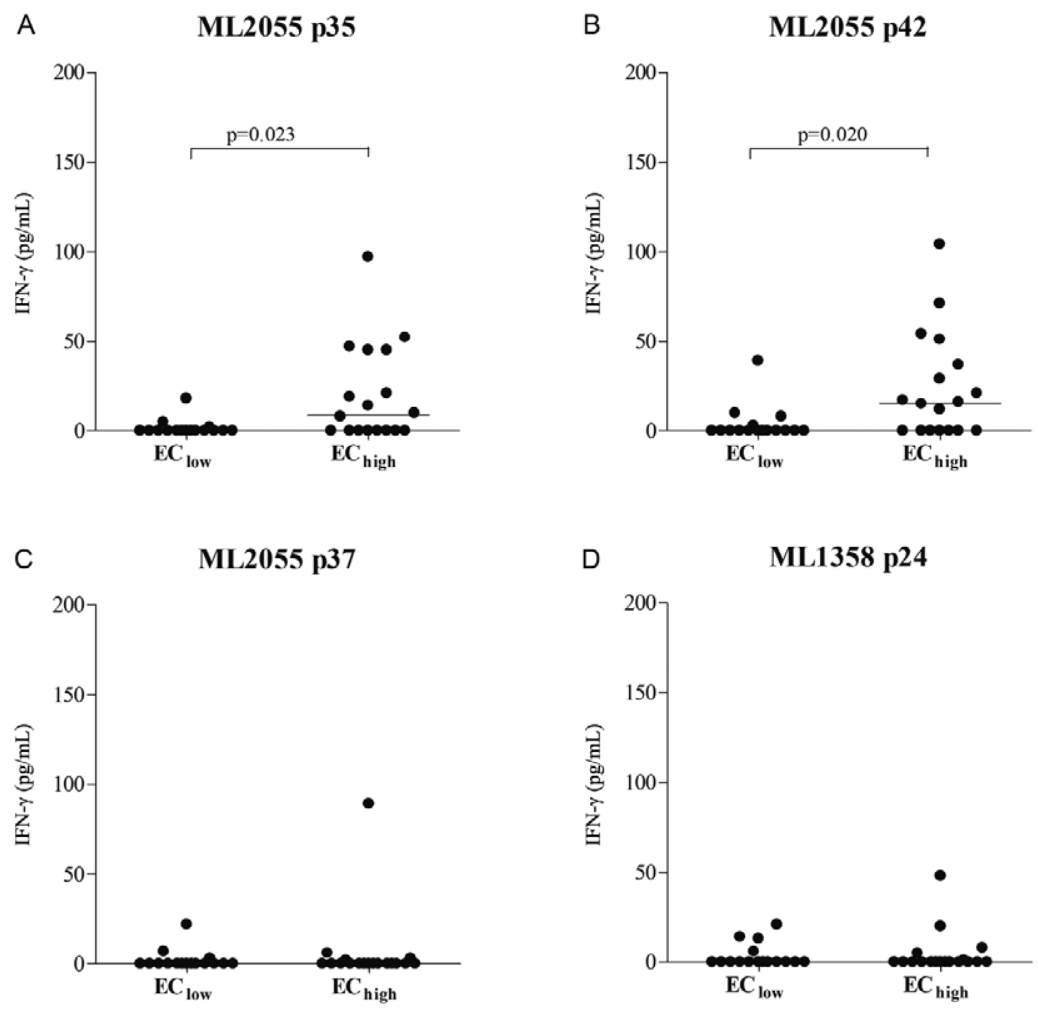

E

F

ML2055 p42
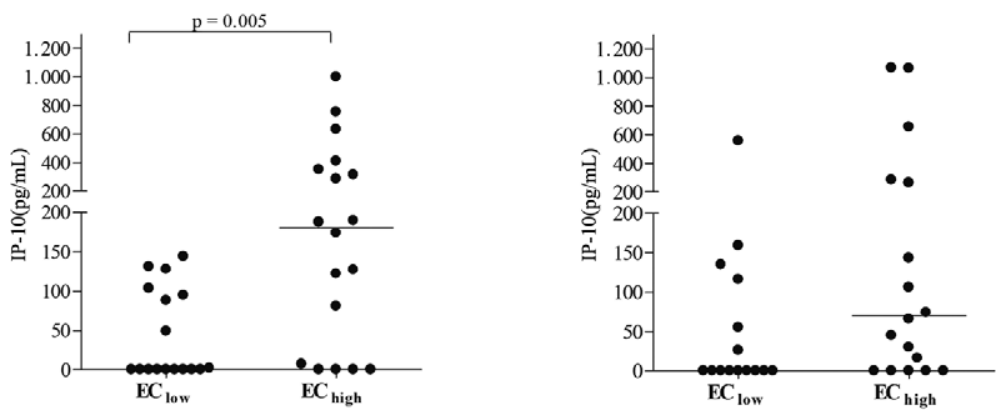

Fig. 4: interferon (IFN)- $\gamma$ and induced protein-10 (IP-10)responses to Mycobacterium leprae virulence-associated peptides in $24 \mathrm{~h}$ whole blood assays $(\mathrm{WBA})$ in Ethiopian high prevalence $\left(\mathrm{EC}_{\text {high }}\right)$ and low prevalence $\left(\mathrm{EC}_{\text {low }}\right)$ leprosy IFN- $\gamma(\mathrm{A}-\mathrm{D})$ and IP-10 (E, F) production in response to M. leprae peptides ML2055 p35 (A, E), ML2055 p42 (B, F), ML2055 p37 (C) and ML1358 p24 (D) in 24 h WBA of EC low $_{\text {healthy individuals }}$ from areas in Ethiopia with leprosy prevalence of $0.36 / 10,000(\mathrm{n}=17)$ and $\mathrm{EC}_{\text {high }}$ healthy individuals from areas with prevalence of $1.5 / 10,000$ $(\mathrm{n}=18)$. Responses are corrected for background values. Median values per test group are indicated by horizontal lines. 


\section{DISCUSSION}

Every year, more than 200,000 people are newly diagnosed with leprosy at health facilities worldwide. The majority of these cases are multibacillary leprosy (MB) patients, which include a considerable proportion of grade 2 cases and paediatric cases (WHO 2011). The lack of tools for the early detection of leprosy and complications in leprosy reactions represent the most important challenges in combating leprosy (Scollard 2005, Scollard et al. 2006).

A

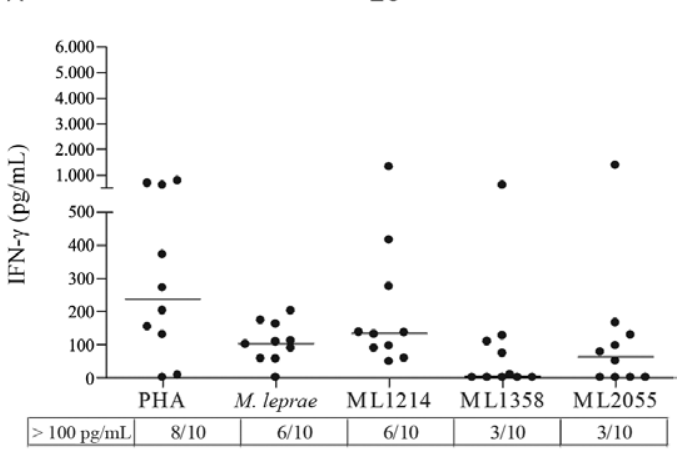

B

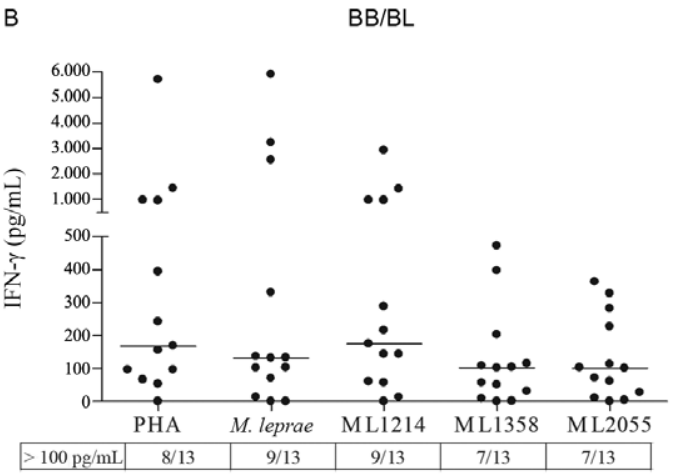

C

$\mathrm{HHC}$

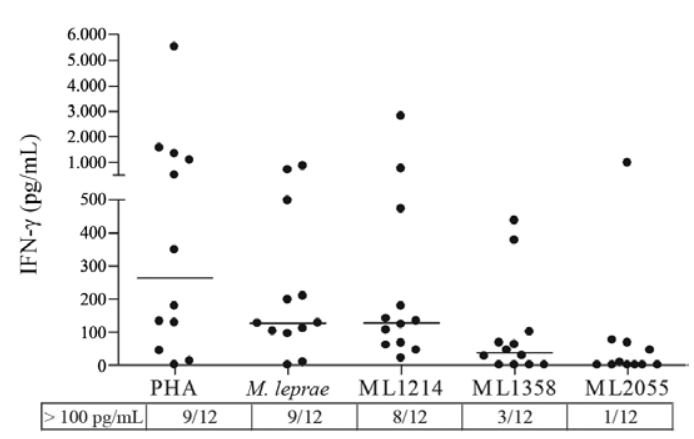

Fig. 5: interferon (IFN)- $\gamma$ responses to newly identified Mycobacterium leprae virulence-associated proteins. IFN- $\gamma$ production (corrected for background values) induced using $M$. leprae recombinant proteins ML1214, ML1358 and ML2055 in $24 \mathrm{~h}$ whole blood assays from endemic controls $(\mathrm{EC})(\mathrm{A})(\mathrm{n}=10)$, borderline lepromatous/lepromatous leprosy $(\mathrm{BL} / \mathrm{LL})(\mathrm{B})(\mathrm{n}=13)$ and house hold contacts $(\mathrm{HHCs})(\mathrm{C})(\mathrm{n}=$ 12) in Ethiopia. PHA: phytohaemagglutinin.
The availability of full genome sequences from several organisms and the application of advanced bioinformatics have facilitated the search for unique leprosy antigens (Dockrell et al. 2000, Spencer et al. 2005, Geluk et al. 2008, 2009, 2011, Bobosha et al. 2011). The current study builds upon our previous studies (Geluk et al. 2005, 2009, 2010, Spencer et al. 2005). However, instead of using hypothetical peptides derived from the VI group (M. leprae proteins with unknown functions), this study analysed peptides that were derived from virulence-associated M. leprae proteins (group IV.A). Twenty-nine M. leprae virulence-associated synthetic peptides were selected using a bioinformatics-supported approach to predict unique $M$. leprae sequences. Potential HLA class I and II peptide sequences were derived and subsequently tested in patients from different leprosy endemic regions on three continents to determine the peptides' potential to detect $M$. leprae exposure/infection.

The peptides that induced T-cell reactivity in leprosy patients or healthy individuals living in regions that are hyper endemic for leprosy $\left(\mathrm{EC}_{\text {high }}\right)$ were predominantly derived from the following three M. leprae-unique proteins: ML2055, ML1358 and ML1214. Consistent with the IFN- $\gamma$ production that was observed in response to the ML2055 peptides, seven out of 13 leprosy patients and three out of seven of the Ethiopian $\mathrm{EC}_{\text {high }}$ group also responded to the ML2055 recombinant protein.

The differences in the M. leprae peptide recognition patterns that were observed in this study between leprosy patients and the $\mathrm{EC}_{\text {high }}$ groups compared with the $\mathrm{EC}_{\text {low }}$ groups, implies that the unique peptides have potential use in estimating of the level of $M$. leprae exposure in individuals. This function was also recently described for ML1601-derived peptides (Bobosha et al. 2012). Interestingly, the ML2055 p35 and ML2055 p42 peptides were recognised by both the Brazilian and Ethiopian leprosy patients. Moreover, these two peptides induced significant levels of IFN- $\gamma$ and IP-10 in the Ethiopian $\mathrm{EC}_{\text {high }}$ group, suggesting that the ML2055 p35 and ML2055 p42 peptides can detect $M$. leprae exposure in populations with diverse HLA-alleles. ML2055 has also been reported to induce strong serological responses in lepromatous patients (Sampaio et al. 2011). The low response against ML2055 in the Ethiopian HHC group compared with the EC group could have been a result of an overexposure to mycobacteria. This effect is possible in the HHCs of the MB patients and could have resulted in T cell downregulation, as hypothesised recently (Martins et al. 2012).

We also observed differences in the peptide recognition patterns between the Brazilian $\mathrm{EC}_{\text {high }}$ group (ML1358 p20 and ML1358 p24 peptides) and the Ethiopian $\mathrm{EC}_{\text {high }}$ group(ML2055 p35 and ML2055 p42 peptides). This discrepancy is a reflection of the different HLA polymorphisms in these regions. Both groups of peptides may be useful for indicating $M$. leprae exposure because neither the Brazilian nor the Ethiopian $\mathrm{EC}_{\text {low }}$ groups responded to these peptides. However, a longitudinal analysis of the $\mathrm{T}$-cell responses that were induced by these peptides in a cohort of $\mathrm{EC}_{\text {high }}$ and individuals with household contacts with MB patients at multiple leprosy endemic sites may 
A

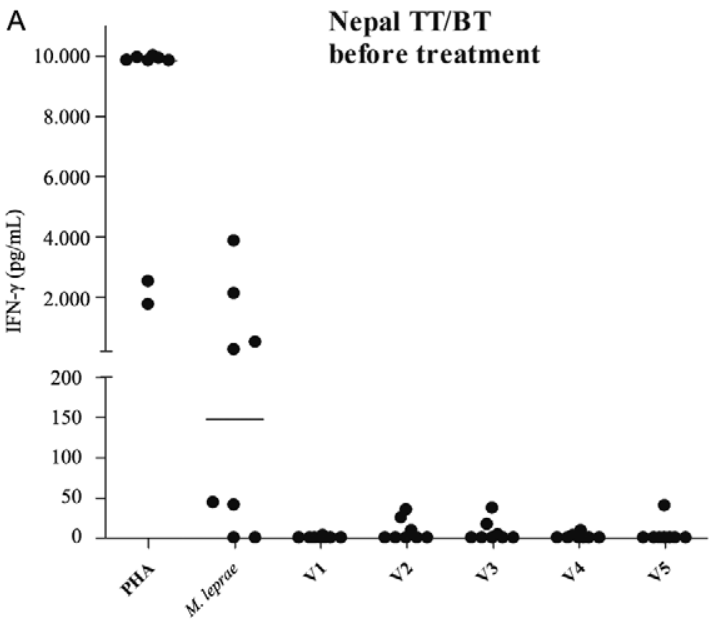

M. leprae peptide pools

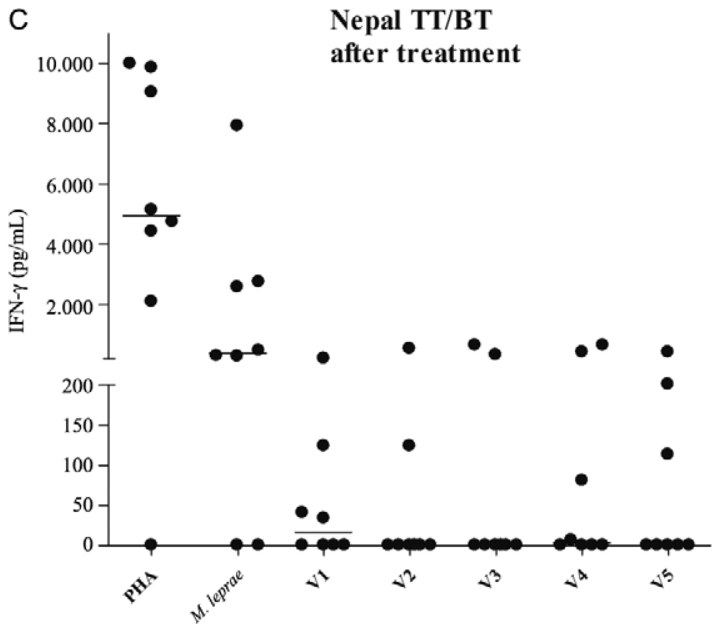

M. leprae peptide pools

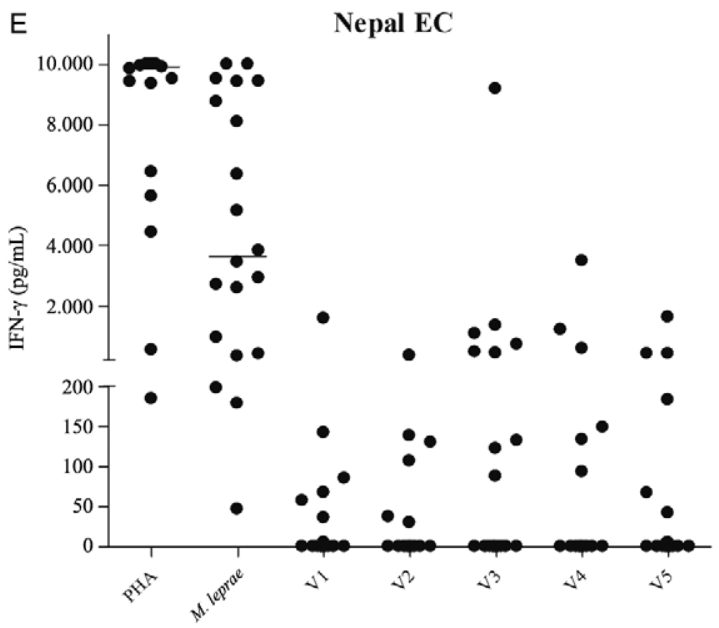

B

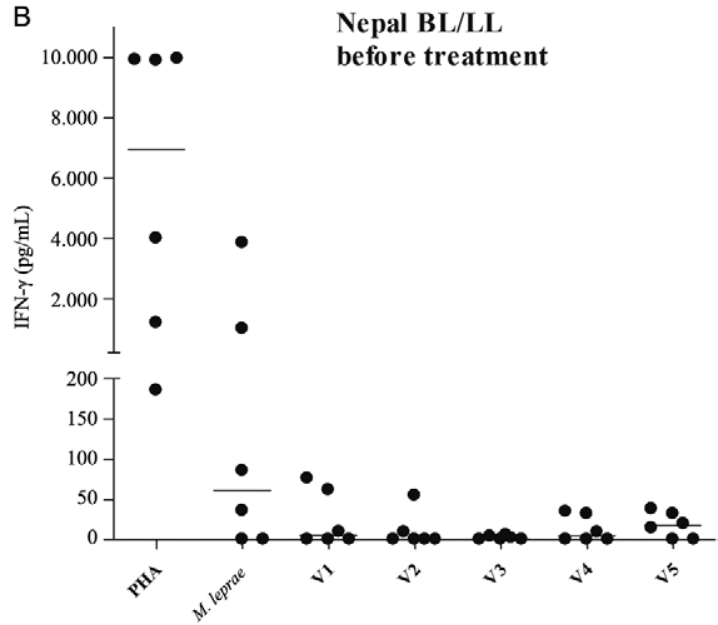

M. leprae peptide pools

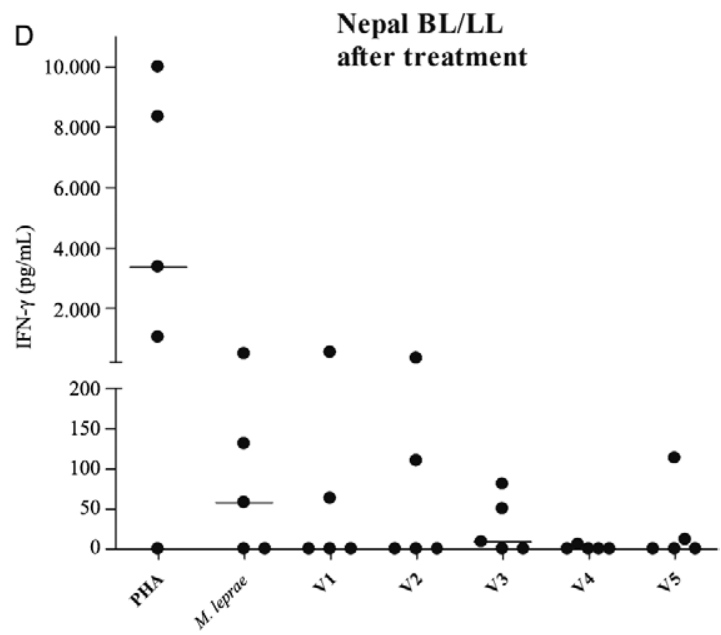

M. leprae peptide pools

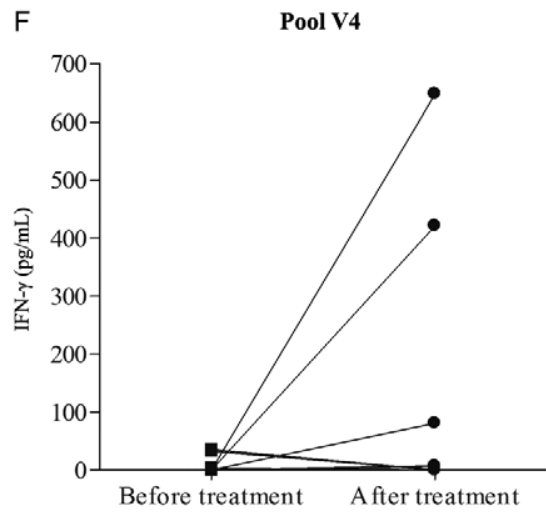

M. leprae peptide pools

Fig. 6: interferon (IFN)- $\gamma$ responses to Mycobacterium leprae virulence-associated peptide pools in peripheral blood mononuclear cell (PBMC) from Nepali individuals. IFN- $\gamma$ production (corrected for background values) induced by pools of $M$. leprae virulence-associated peptides (10 $\mu \mathrm{g} / \mathrm{mL}$ each) in six days PBMC cultures of borderline tuberculoid (BT) (A) $(\mathrm{n}=7)$ and borderline lepromatous/lepromatous leprosy (BL/LL) (B) $(\mathrm{n}=5)$ patients before and after multidrug therapy $(\mathrm{C}, \mathrm{D}$, respectively) and endemic controls (EC) (E) $(\mathrm{n}=20)$. IFN- $\gamma$ responses of all leprosy patients before and after treatment in response to pool V4 (F). Pool V1: p15-p20; V2: p21-p26; V3: p27-p32; V4: p33-p35, p37-p39; V5: p36, p40p43. PHA: phytohaemagglutinin. 
determine whether these peptides can be used to predict disease progression or merely to indicate the level of M. leprae exposure.

The benefits of testing peptide pools to detect potential epitopes among several candidate peptides has been reported previously (Geluk et al. 2008). The combination of peptides, as applied in the QuantiFERON ${ }^{\circledR}$-TB test for TB diagnostics (Chegou et al. 2009), can cover a wider range of HLA alleles compared with using single peptides (Ottenhoff et al. 1991, Geluk et al. 1992, 2005, 2009, Spencer et al. 2005, Geluk \& Ottenhoff 2006).

Therefore, the M. leprae virulence-associated peptides were additionally tested in four-six peptide pools in Nepali ECs and in patient (TT/BT/BL/LL) groups both before and after treatment. Three peptide pools (V3, V4 and V5) that included immunogenic peptides (ML2055 p35, ML2055 p37 and ML2055 p42) and induced an IFN- $\gamma$ response in the Brazilian and Ethiopian individuals were observed to cause a significant induction of the Th1 response in Nepali ECs (Fig. 6E). In contrast, a small response was detected in leprosy patients prior to MDT (Fig. 6A, B). However, after MDT, certain BT patients displayed a significantly increased IFN- $\gamma$ response in response to the peptide pools and against $M$. leprae (Fig. 6D). This change reflects an improved cellular immune response against $M$. leprae after MDT. The low or absent IFN- $\gamma$ response that was detected for BL/LL patients was consistent with their lepromatous phenotype, which lacked a Th1 immune response.

The immune response against $M$. leprae infection is a collective/synergistic response of various immune cascades that involve both the induction of cytokines and chemokines by innate and adaptive immune cells. IFN- $\gamma$ has been known as an indicator of a Th1 response and the utility of this cytokine will depend on the specificity of the stimulus used in the analysis. In addition to IFN- $\gamma$, other cytokines and chemokines, such as IP-10, may have potential as markers to distinguish

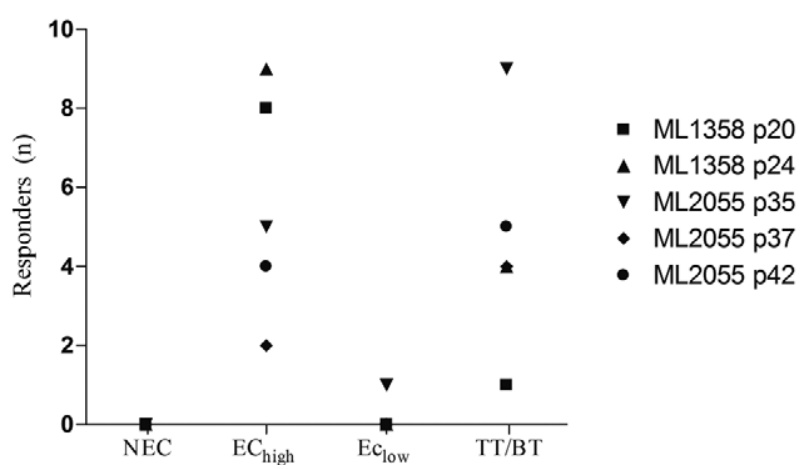

Fig. 7: individuals with interferon (IFN)- $\gamma$ responses to Mycobacterium leprae virulence-associated peptides. The total number of individuals that induced IFN- $\gamma$ production in response to five promising $M$. leprae virulence-associated peptides is indicated for each test group: Dutch non-endemic controls (NEC) $(\mathrm{n}=8)$, combined Brazilian and Ethiopian $\mathrm{EC}_{\text {high }}(\mathrm{n}=28)$, living in high leprosy prevalence area, $\mathrm{EC}_{\text {low }}$ $(\mathrm{n}=27)$ living in low leprosy prevalence area, leprosy and lepromatous leprosy/borderline tuberculoid $(\mathrm{TT} / \mathrm{BT})$ patients $(\mathrm{n}=20)$. between different exposure levels and/or leprosy infection (Bobosha et al. 2012) and TB infection (Chegou et al. 2009). In the current study, the induction of IP-10 in Ethiopian $\mathrm{EC}_{\text {high }}$ individuals in response to the ML2055 p35 and p42 peptides confirms the potential use of this chemokine as a biomarker to specifically indicate $M$. leprae exposure. Additionally, IP-10 can be used in HIV infected patients because, in contrast to IFN- $\gamma$, IP-10 levels were not affected by low CD4 T-cell counts in TB patients with HIV (Aabye et al. 2010). Currently, further studies on the use of IP-10 as a biomarker for the diagnosis of leprosy in $\mathrm{HIV}^{+}$individuals are on-going at our Ethiopian test site.

The main advantage arising from the use of synthetic peptides compared with the use of proteins is that peptides less frequently induce T-cell cross reactivity (Spencer et al. 2005). However, because of the HLA-restriction of peptides that are recognised by T-cells, single peptides are not able to cover diverse populations. In this study, we show that the ML2055 p35 and the ML2055 p42 peptides, in addition to the ML1358 p20 and ML1358 p24 peptides, were recognised by patients and $\mathrm{EC}_{\text {high }}$ individuals in both Brazil and Ethiopia. In addition, peptide pools induced an IFN- $\gamma$ response in $30-40 \%$ of Nepali ECs. Therefore, similarly to TB diagnostics, analysis of IFN- $\gamma$ and other cytokines, such as IP-10, after stimulation with combinations of $M$. leprae (virulence-associated) peptides will be helpful in developing new tools for the detection of $M$. leprae exposure/infection.

\section{ACKNOWLEDGEMENTS}

To all patients and blood donors, to Yonas Fantahun, Genet Amare and Dr Saba M Lambert, from AHRI/ALERT, Kapil Neupane (MRL) and clinical staff from Anandaban Hospital, for help with recruitment of blood donors, to Mette Voldby Larsen, for technical assistance, and to Jiu Neng William Lee, for assistance with writing the software of the GenomePatterns program.

\section{REFERENCES}

Aabye MG, Ruhwald M, Praygod G, Jeremiah K, Faurholt-Jepsen M, Faurholt-Jepsen D, Range N, Friis H, Changalucha J, Andersen AB, Ravn P 2010. Potential of interferon-gamma-inducible protein 10 in improving tuberculosis diagnosis in HIV-infected patients. Eur Respir J 36: 1488-1490.

Araoz R, Honore N, Cho S, Kim JP, Cho SN, Monot M, Demangel C, Brennan PJ, Cole ST 2006. Antigen discovery: a postgenomic approach to leprosy diagnosis. Infect Immun 74: 175-182.

Arend SM, Andersen P, van Meijgaarden KE, Skjot RL, Subronto YW, van Dissel JT, Ottenhoff TH 2000. Detection of active tuberculosis infection by $\mathrm{T}$ cell responses to early-secreted antigenic target 6-kDa protein and culture filtrate protein 10. J Infect Dis 181: 1850-1854.

Bobosha K, van der Ploeg-van Schip JJ, Esquenazi DA, Guimaraes MM, Martins MV, Bekele Y, Fantahun Y, Aseffa A, Franken KL, Gismondi RC, Pessolani MC, Ottenhoff TH, Pereira GM, Geluk A 2012. Peptides derived from Mycobacterium leprae ML1601c discriminate between leprosy patients and healthy endemic controls. J Trop Med 2012: e132049.

Bobosha K, van der Ploeg-van Schip JJ, Zewdie M, Sapkota BR, Hagge DA, Franken LMK, Inbiale W, Aseffa A, Ottenhoff TH, Geluk A 2011. Immunogenicity of Mycobacterium leprae unique antigens in leprosy endemic populations in Asia and Africa. Lepr Rev 82: 445-458. 
Britton WJ, Lockwood DN 2004. Leprosy. Lancet 363: 1209-1219.

Chegou NN, Black GF, Kidd M, van Helden PD, Walzl G 2009. Host markers in QuantiFERON supernatants differentiate active TB from latent TB infection: preliminary report. BMC Pulm Med 9: 21.

Cole ST, Eiglmeier K, Parkhill J, James KD, Thomson NR, Wheeler PR, Honore N, Garnier T, Churcher C, Harris D, Mungall K, Basham D, Brown D, Chillingworth T, Connor R, Davies RM, Devlin K, Duthoy S, Feltwell T, Fraser A, Hamlin N, Holroyd S, Hornsby T, Jagels K, Lacroix C 2001. Massive gene decay in the leprosy bacillus. Nature 409: 1007-1011.

Dockrell HM, Brahmbhatt S, Robertson BD, Britton S, Fruth U, Gebre N, Hunegnaw M, Hussain R, Manandhar R, Murillo L, Pessolani MC, Roche P, Salgado JL, Sampaio E, Shahid F, Thole JE, Young DB 2000. A postgenomic approach to identification of Mycobacterium leprae-specific peptides as T-cell reagents. Infect Immun 68: 5846-5855.

Franken KL, Hiemstra HS, van Meijgaarden KE, Subronto Y, den HJ, Ottenhoff TH, Drijfhout JW 2000. Purification of his-tagged proteins by immobilized chelate affinity chromatography: the benefits from the use of organic solvent. Protein Expr Purif 18: 95-99.

Geluk A, Duthie MS, Spencer JS 2011. Postgenomic Mycobacterium leprae antigens for cellular and serological diagnosis of M. leprae. Lepr Rev 82: 402-421.

Geluk A, Klein MR, Franken KL, van Meijgaarden KE, Wieles B, Pereira KC, Bührer-Sékula S, Klatser PR, Brennan PJ, Spencer JS, Williams DL, Pessolani MC, Sampaio EP, Ottenhoff TH 2005. Postgenomic approach to identify novel Mycobacterium leprae antigens with potential to improve immunodiagnosis of infection. Infect Immun 73: 5636-5644.

Geluk A, Ottenhoff TH 2006. HLA and leprosy in the pre and postgenomic eras. Hum Immunol 67: 439-445.

Geluk A, Spencer JS, Bobosha K, Pessolani MC, Pereira GM, Banu S, Honore N, Reece ST, Macdonald M, Sapkota BR, Ranjit C, Franken KL, Zewdie M, Aseffa A, Hussain R, Stefani MM, Cho SN, Oskam L, Brennan PJ, Dockrell HM 2009. From genome-based in silico predictions to ex vivo verification of leprosy diagnosis. Clin Vaccine Immunol 16: 352-359.

Geluk A, van der Ploeg J, Teles RO, Franken KL, Prins C, Drijfhout JW, Sarno EN, Sampaio EP, Ottenhoff TH 2008. Rational combination of peptides derived from different Mycobacterium leprae proteins improves sensitivity for immunodiagnosis of $M$. leprae infection. Clin Vaccine Immunol 15: 522-533.

Geluk A, van der Ploeg-van Schip JJ, van Meijgaarden KE, Commandeur S, Drijfhout JW, Benckhuijsen WE, Franken KL, Naafs B, Ottenhoff TH 2010. Enhancing sensitivity of detection of immune responses to Mycobacterium leprae peptides in whole-blood assays. Clin Vaccine Immunol 17: 993-1004.

Geluk A, van Meijgaarden KE, Janson AA, Drijfhout JW, Meloen RH, de Vries RR, Ottenhoff TH 1992. Functional analysis of DR17(DR3)-restricted mycobacterial T-cell epitopes reveals DR17-binding motif and enables the design of allele-specific competitor peptides. J Immunol 149: 2864-2871.

Larsen MV, Lundegaard C, Lamberth K, Buus S, Brunak S, Lund O, Nielsen M 2005. An integrative approach to CTL epitope pre- diction: a combined algorithm integrating MHC class I binding, TAP transport efficiency and proteasomal cleavage predictions. Eur J Immunol 35: 2295-2303.

Martins MV, Guimarães MM, Spencer JS, Hacker MA, Costa LS, Carvalho FM, Geluk A, van der Ploeg-van Schip JJ, Pontes MA, Gonçalves HS, de Morais JP, Bandeira TJ, Pessolani MC, Brennan PJ, Pereira GM 2012. Pathogen-specific epitopes as epidemiological tools for defining the magnitude of Mycobacterium leprae transmission in areas endemic for leprosy. PLoS Negl Trop Dis 6: e1616.

Ottenhoff TH, Haanen JB, Geluk A, Mutis T, Ab BK, Thole JE, van Schooten WC, van den Elsen PJ, de Vries RR 1991. Regulation of mycobacterial heat-shock protein-reactive T-cells by HLA class II molecules: lessons from leprosy. Immunol Rev 121: 171-191.

Ridley DS, Jopling WH 1966. Classification of leprosy according to immunity. A five-group system. Int J Lepr Other Mycobact Dis 34: $255-273$.

Ruhwald M, Bjerregaard-Andersen M, Rabna P, Kofoed K, EugenOlsen J, Ravn P 2007. CXCL10/IP-10 release is induced by incubation of whole blood from tuberculosis patients with ESAT-6, CFP10 and TB7.7. Microbes Infect 9: 806-812.

Ruhwald M, Dominguez J, Latorre I, Losi M, Richeldi L, Pasticci MB, Mazzolla R, Goletti D, Butera O, Bruchfeld J, Gaines H, Gerogianni I, Tuuminen T, Ferrara G, Eugen-Olsen J, Ravn P 2011. A multicentre evaluation of the accuracy and performance of IP-10 for the diagnosis of infection with M. tuberculosis. Tuberculosis (Edinb) 91: 260-267.

Sampaio LH, Stefani MM, Oliveira RM, Sousa AL, Ireton GC, Reed SG, Duthie MS 2011. Immunologically reactive $M$. leprae antigens with relevance to diagnosis and vaccine development. $B M C$ Infect Dis 11: 26.

Scollard DM 2005. Leprosy research declines, but most of the basic questions remain unanswered. Int J Lepr Other Mycobact Dis 73: 25-27.

Scollard DM, Adams LB, Gillis TP, Krahenbuhl JL, Truman RW, Williams DL 2006. The continuing challenges of leprosy. Clin Microbiol Rev 19: 338-381.

Singh H, Raghava GP 2003. ProPred1: prediction of promiscuous MHC class-I binding sites. Bioinformatics 19: 1009-1014.

Spencer JS, Dockrell HM, Kim HJ, Marques MA, Williams DL, Martins MV, Martins ML, Lima MC, Sarno EN, Pereira GM, Matos H, Fonseca LS, Sampaio EP, Ottenhoff TH, Geluk A, Cho SN, Stoker NG, Cole ST, Brennan PJ, Pessolani MC 2005. Identification of specific proteins and peptides in Mycobacterium leprae suitable for the selective diagnosis of leprosy. J Immunol 175: 7930-7938.

Sturniolo T, Bono E, Ding J, Raddrizzani L, Tuereci O, Sahin U, Braxenthaler M, Gallazzi F, Protti MP, Sinigaglia F, Hammer J 1999. Generation of tissue-specific and promiscuous HLA ligand databases using DNA microarrays and virtual HLA class II matrices. Nat Biotechnol 17: 555-561.

Truman RW, Krahenbuhl JL 2001. Viable M. leprae as a research reagent. Int J Lepr Other Mycobact Dis 69: 1-12.

WHO - World Health Organization 2011. Leprosy update 2011. Wkly Epidemiol Rec 86: 389-399. 